Latin America, New Ruralities | 112

NORMA GIARRACCA'

\title{
Social Sciences and Rural Studies in Argentina during the 20 th century
}

\section{Introduction}

This work intends to provide a broad overview of social science contributions in the study of Argentinian agrarian processes and rural contexts. It is intended as a way of organising the literature without too much of a focus on its theoretical or methodological underpinnings. Regardless, the mere fact of selecting some works and not others involves decisions that are not exempt from some kind of academic evaluation. This is evident particularly in the last period in which, surprisingly, I found an abundant and heterogenous production.

However, it is not my intention to conduct an analysis that includes putting into hierarchies theoretical value of this production or the influence that this material had over political decisions during each period. This task starts, slowly, with some contributions aimed at evaluating the conceptualisations of a discipline (Llovet, 1996) or an issue (Barsky, 1997). We can also find my own reflections about how the crisis of theoretical paradigms affected Rural Sociology (Giarracca, 1997).

I have collected the material and started ordering it according to thematical axes that were dominant in the debates during each era, and, in second place, I address some reflections about the institutional hurdles that these social disciplines went through in each stage. All of this is preceded by a general overview of the period.

The "social perspective", which in the title of this work is expressed as "Social Sciences", supposes an epistemic discussion that is not my intention to address here;

\footnotetext{
'This text is a translation from the original: GIARRACCA, NORMA (1999). "Las ciencias sociales y los estudios rurales en la. Argentina durante el siglo XX."

2 This article has been translated by M. Eugenia Giraudo. This article was originally published in http://www.alternautas.net/blog/2021/1/26/social-sciences-and-rural-studies-in-argentinaduring-the-2oth-century
} 
I simply started from empirical decisions, conditioned by my own professional practices. I put works on Sociology, Social Anthropology, Human Geography, History and Political Economy in this category.

For equally empirical reasons, four periods are delineated to locate and contextualise the identified material. The first is marked by an academic event: before and after the emergence of Social Sciences as institutionalised disciplines; the other three, are marked by political events in our country.

The first period includes the first six decades of this century, previous era to which is considered the "professionalization of the Social Sciences". In it I include authors that, without being academic "professionals", had a significant influence in the following development of the social disciplines referred to here.

The second period covers from the end of the 1950s - which is the moment of institutionalisation of the Social Sciences as university degrees - until 1976. It was a very productive stage, that entailed one of the most fruitful periods of Argentine university, as that of the work of top-level technical teams of the state (see Giarracca, 1991).

In the third period we consider the years of the 'military process' and is an attempt to acknowledge the systematic dismantling of study centres and working teams that functioned in universities and state agencies. Additionally, the organizational attempts of the end of the dictatorship are recovered.

Finally, the last period, that I take as a bloc for practical reasons, could be subdivided around agrarian process as well as to rural studies. Regarding the first point, it is the moment of agriculturization, particularly the soybean peak. Later there is a productive retraction and the most impactful political measure of this part of the century occurs: economic deregulation (1991). Moreover, it is the moment of normalization of universities, re-organised in groups, generating resources from masters and scholarship programmes. It is also the period of emergence of MERCOSUR, of the height of neoliberal policies but also of academic networks, expansion of information technology, etc. It is a complex period: because of the changes in the country as a whole, because of the novelties in the agrarian world, and for the turns in the frameworks to understand them. It would imply a job in and of itself and, in that sense, this first organisation of the material could be of great use to that end. 
To end this introduction I would like to point out the organisation of the text in connection with the bibliography. The reader will find two types of bibliographical references: 1) the bibliography that is connected to the text in its character of a Sociology of rural studies - with author and year in between brackets - and which is found at the end of the article under the title "Cited bibliography", 2) the bibliography about rural studies that is found in-text or at the end of the paragraph, with the indication of authors and dates but always with a reference to the "General bibliography". ${ }^{3}$ Under this last subtitle the reader will find at the end, as an annex to the book, an alphabetical organisation of the authors that during this century have contributed to know and understand the agrarian productive processes and the rural worlds in its social and cultural complexities. It was my intention to select the most representative pieces of work from each period or each author. Even if there are some absences, errors, and involuntary confusions in the selection, typical of any organisational action and classification, it is a first task that can stimulate its continuation and improvement.

\section{First period: agrarian social thinking (1900-1956)}

From the end of the $19^{\text {th }}$ century until the 1930s, the Argentine agricultural sector generated important surpluses that led to dazzling economic progress of the country. This expansive period, based on a "capitalist agro-exporter" mode of production, was favoured by international conditions that stimulated external demand of the Pampas region, both by the high process of agricultural products as for the settlement of populations in the extensive and fertile available lands. There was a process of horizontal expansion, in which production increased because of the incorporation of new lands. When this resource was exhausted, the expansion rhythm slowed down considerably.

During this stage, the main problems to be solved made discussions - both academic and political - to turn around the necessary elements for the beginning of production in these lands that were being incorporated to the advancement of the frontier line: settlement of labour apt for agriculture, colonisation, and property of land. Labour

\footnotetext{
3 Por motivos de extensión y pertinencia, al final del presente artículo, bajo el título común de "Bibliografía", se incluyen conjuntamente la bibliografía citada en él y las referencias explícitas a la "Bibliografía general" (extenso anexo final del libro). Para conocer la "Bibliografía general" a la que hace referencia el párrafo, véase la publicación original. [N. de los Ed.]
} 
saving technologies were provided as a way of solving said problems, what contributed to establishing a productive structure that - when international conditions changed - responded with a retraction.

A stage thus began that was known as the Pampas stagnation that lasted until 1970s. Indeed, the hardest moment extended from 1930 to 1960; from this last date the situation began to improve, even when difficulties remained to maintain the country's relative participation in world's trade of grains, meat, and oilseeds. This inability to respond to international demands, and simultaneously the increase in supply of other producing nations, did not allow the country to continue being as productive as it might be. In relative terms, the stagnation persisted.

Given the role that the agricultural sector plays in the historically established accumulation model and, within it, the relevance of exports, the stagnation of the Pampas region shook society to its core. Moreover, the strong link between the sector and the rest of the economy manifested in the political economy orientation developed by the state. In the same period, regional economies underwent severe production crises that generated different types of state interventions as well as diverse social consequences.

During this period, we need to refer to "agrarian social thinking" more than production in Social Sciences. And it is so, simply, because these scientific disciplines did not exist in the way we know them today. The "profession" of social researcher had not emerged, that is, full-time university or institutional positions that allowed the economic sustenance of social analysis. In this way, "agrarian social thinking" was created by economic and political leaders and by technocrats in state agencies.

The debate in the beginning of the century was marked by positivist thinking. This influence was so strong that the idea of progress as an unlimited process dazzled thinkers of all strands. Several authors, influences by socialist thinking, asked themselves about the reasons why some sectors could not access progress, but did not question the origin or nature of these processes. The crisis of 1930 marked the end of this idea of unlimited progress. The period of relative stagnation of the Pampas economy gave origin to different positions and debates.

In his book Argentine Agriculture and Ranching in the period 1930-1960, José Alfredo Martínez de Hoz synthesised the position of one of the most powerful sectors within agriculture, that represented by the Argentine Rural Society (Sociedad Rural Argentina). In this work the author argued that the increase in yielding would only 
be achieved through a better technification of agriculture. The country, according to Martínez de Hoz, was stuck in technical isolation, in the rear of progress, because of the 1930s crisis, then because of the war, because of the policy developed by the Peronist government, and because of the erroneous price policies and financial and fiscal measures that unfavoured the sector.

Other authors took different positions, more structuralist ones; they came, usually, from the socialist field. In that sense, Lázaro Nemirovsky conducted an exhaustive study (his doctoral thesis) about prices and profit margins obtained by large landholders (terratenientes), to support his argument about the need for changes in the social structure, capable of overcoming the stagnation.

Juan L. Tenembaum, professor of the Agrarian Economy Cátedra at Universidad de La Plata, in his book Economic Orientation of the Argentine Agriculture published in 1948 demonstrated the change occurred from 1930, yearn in which the crisis began to be felt in full. He was in favour of the agrarian-pastoral system over the pastoralagrarian one because, in his opinion, it ensured a more stable economic regime. His arguments tended to demonstrate the need for an agrarian-industrial development as the only possibility for overcoming an exhausted stage. The prologue of his book, written by Luis Reissig, proposed:

His thesis coincides with the political thinking that should prevail in the stage of a progressive democracy. The world opens to a succession of deep reforms, among which, the agrarian and the industrial will have to occupy a vanguard place in the development of the new world (1948:7).

During 1943, Carl Taylor visited the country invited by the Ministry of Agriculture and Ranching. Taylor was a North American expert in agrarian productive organizations and the fruit of his work was his book Rural Life in Argentina considered a "classic" by sociologists and rural anthropologists. The author visited the majority of agrarian areas of the country, interviewed more than 120 people representative of the sector, talked to journalists, union leaders, ministers, producers, hourly-paid workers, and university professors. His work - unfortunately never translated to Spanish - manifested one of the most important Latin American debates of the time: the role of the medium family exploitation (farm) in the development of capitalism. This author, an official at the U.S. Department of Agriculture, regretted in his book the little dissemination of the farmer model in our country; one of his conclusions argued that the main obstacle to its implementation was the predominant property system. 
The theoretical and methodological influence of Carl Taylor was notorious for several years. ${ }^{4}$ Proof of this were the works published by the Direction of Rural Economy of the Ministry during 1940 and 1950: the work by Vicien and Del Castillo, Agrarian Social Regions, published in 1943 and updated in 1952.

Moreover, during those same years, the Group of Rural Sociology emerged within the Ministry of Agriculture. The analysis of that first team that worked under that name recognized not only the influence of North American Rural Sociology, but of Human Geography strongly developed in France.

At the same time began a flourishing of Social Sciences as institutionalized scientific disciplines.

Here we ought to highlight the important effort of the founder of the degree in Sociology at the Universidad de Buenos Aires (UBA), Gino Germani, not only to open up the space of this discipline in the Argentine university, but in the scientific sector more generally. During the 1940s several courses in Sociology and Economy were created in different universities, the Institute of Sociology was created in UBA and the first evidence of the European influence in social thinking appeared. Towards the end of the 1950s, university degrees in the main social disciplines began to be created. In spite of all the difficulties that universities suffered, from then on, a systematic production of these disciplines began (see Giarracca, 1991 and 1992).

\section{Second period: the institutionalisation of Social Sciences (1957-1976)}

This second period was characterised by the alternation between civilian and military governments. In the economic sphere, the growth model based on import substitution began to show signs of exhaustion and there were no policies capable of solving the continuous crisis in the balance of payments. While industrialisation showed clear evidence of disarticulations and contradictions among different elements of the industrial bourgeoisie, it still allowed for intervals of redistribution that can be placed within those moments of democratic space of our society. The industrial reactivation was corresponded with an increase in the imports of capital goods, industrial sectors lobbied to keep a low exchange rate and this was unfavourable to export sectors, among which the agricultural and pastoral sector was the most important one.

\footnotetext{
${ }^{4}$ See, in this same book, the chapter "Carl Taylor's thinking", of Floreal Forni.
} 
At the agrarian level, during almost all the period the main preoccupation surrounded the relative stagnation of production in the Pampas and the most appropriate policies to overcome this situation. The overproduction crisis of regional economies had significative consequences at the level of the conflictual productive structures and the social sectors involved. There was an important restructuration of trade unions in the region and social conflict was exacerbated.

During the 1960s, there appeared, on one hand, new and significant contributions from Social Theory. And on the other hand, a rich debate between neoclassic and structuralist economists. This confrontation was present in all of Latin America but had certain particularities in this country given its specific agrarian development within the region.

The thought of the Economic Commission for Latin America and the Caribbean (ECLAC), a clear example of the structuralist thinking, argued for the need to transform the agricultural sector into the necessary role that this sector played in the development of nations. Development which, according to ECLAC, should be based on the industrial sector. That is, the agricultural sector had to be made to fit the needs of industrial development, key axis of growth and general wellbeing.

ECLAC pointed out two elements of the Latin American agricultural problem that needed to be carefully considered: a) the slowness of growth linked to specific agrarian structures, and b) the organisation of property and land tenancy. Both elements deserved careful studies in the majority of countries in the region. At the theoretical level, structuralism tried to incorporate and formulate concepts capable of recognising the Latin American reality and opposing, in this way, to the automation and universality of the development process implicit in the neoclassical thinking.

Opposed to structuralism, neoclassic thinkers abstracted the social context in which production took place. This school was based on a solid intellectual tradition and the most significant representative for Latin America was Theodore Schultz.

For Schultz, the differences within Latin American agricultures reflected the degree of contribution to economic growth that each of them provided. He characterised traditional agricultures in terms of its own rationalisation and proposed their modernisation through the availability of new means of production of high profitability. The solution to the problem was addressed in terms of individual decisions and not of the general context that limited these decisions. 
For neoclassic thinkers, public policies in Latin America were inspired by industrialist principles and had generated that agricultural prices were systematically inferior to "shadow prices". Capital flows to the sector were discouraged and prices would go down. In this way, neoclassic theorists concluded, there was a decrease in the profit rate that limited the investment decisions of the producer.

In the same period, simultaneous to the debate between neoclassic and structuralist economists, new contributions from Social Theory emerged. These new trends, that we will characterise in a general way as "dependentistas", proposed, like the Economics structuralism, to understand Latin America with its own theoretical parameters. The analyses of Gunder Frank, Theotonion Dos Santos, Pablo Gonzáles Casanova, Ruy Mauro Marini, challenged assumptions of North American social theories and provided the debate in the academic and the political arena.

The influence of Marxist theory of uneven development and theory of imperialism is found in any of the variants of the dependency school. Astori (1984) holds that the dependency school provided a criticism to the dualist focus that predominated in the sociologic bibliography of the time and hierarchised the conditions of functioning of capitalism related to the world system with an identification of the contradictions associated to this expansion.

In the analytic scheme that considered certain spaces of capitalist expansion as needed by others - capable of generating higher levels of exploitation - it was used to both the relationship between developed and underdeveloped countries as well as for relationships between regions of a same country with different levels of development. The theorisation of an "internal colonialism" was used as a mandatory point of reference go explain the social and regional disarticulations of Latin America, opposing this analytic perspective to the "rural-urban continuous" that had been used by functionalists in previous years.

Towards the end of the period, the influence of theories that debated "the peasant question" increased. Studies about the peasant persistence of disappearance were in their majority conducted in countries where the problem of small-scale production was central. In our country, Social Anthropology had had a poor development, and, with few exceptions, there was not a line of peasant studies. However, the rich discussion that was being proposed in other countries sparked interest in anthropologists and sociologists. Evidence of this were two publications of significant dissemination that were published in 1972 and 1974, respectively. It is: 1) The study of the peasantry, a compilation of contributions by North American Social 
Anthropologie with a prologue by anthropologist Leopoldo Bartolomé, ${ }^{5}$ and 2) the Spanish translation of Theory of peasant organisation, by Alexandre Chayanov, translated and with a prologue by Eduardo Archetti. From these reflections about the theoretical paradigms, we will try to situate the production from this period.

Those years represented a time of great social and political effervescence in the country. There were top level academic centres in universities, and technical teams (with some conceptual autonomy) were proliferating in the apparatus of the state. There was also a small number of private research centres that were created after the University intervention of 1966. Among them we can name the Insitute Di Tella, the Centre for Research in Social Sciences (CICSO) and the Centre for Urban and Regional Studies (CEUR).

The themes that were the focus of Social Sciences were: 1) the stagnation of production in the Pampas; 2) renting and possibilities of production of medium-size production in the Pampas region; 3) the crisis of regional crops; 4) the problem of the agrarian labour force; and 5) producers' trade unions.

The first of these topics was debated mainly by economists and agrarian engineers. The neoclassic interpretations of stagnation came from economists in the Argentine Rural Society and are published in the Annals of the Argentine Rural Society or the newspaper La Nación. In these texts there was an explanation of the slow growth of production in the Pampas because of unfavourable government policies towards the agro-pastoral sector. Policies such as fixed prices, exchange rates, export taxes, and other fiscal measures that discouraged investment and created stagnation.

Unlike the first ones, the so called "structuralist" economists did not look at the stagnation problem as a "sectoral" issue vis-à-vis the state but based their analysis on the role of the landholder of the Pampas as an economic agent of capitalist development. Some of them highlighted the resistance of these producers to introduce more intensive production methods. The considered that large landholders did not act as capitalists in search of profits. This thesis was developed by Aldo Ferrer and Horacio Giberti.

Within the "structuralists", another sub-group of authors was attempting to demonstrate the capitalist rational of extensive exploitations (Guillermo Flichman).

\footnotetext{
${ }^{5}$ See the chapter 'Social anthropology and rurality in Argentina'by Hugo Ratier and Roberto Ringuelet.
} 
Usually, authors that debated the stagnation of the Pampas from this position were Horacio Giberti, Aldo Ferrer, Oscar Braun, Edith Obschatko, Alain de Janvry, Guillermo Flichman, Miguel Teubal, and Alfredo Pucciarelli (even when this last one published his work in the eighties). Decisively, many of these economists did not escape the influence of the neoclassic theories, but asked themselves problems and questions from theoretical spaces influenced by different strands of "critical theories".

The role of medium-size producers in the development of the Pampas and the discussion about the fate of tenants led to research and publications. For example, the work by Daniel Slutsky about "The social aspects of the rural development of the Pampas”, published by the journal Desarrollo Económico, questioned the interpretations that held that most tenants had been able to access the purchase of lands.

The majority of these works took as a starting point and reference the analysis conducted by the Inter-American Committee of Agricultural Development and the Federal Council of Investments (CIDA-CFI). This report highlighted the level of land concentration and presence of the small holding in the Argentine agricultural sector. The information that was analyzed, based on the Agricultural Census of 1960, as well as the historic-structuralist approach, lasted over decades in the studies of the country's agrarian question.

During the mid-1970s, most of the regional crops went through a crisis of different nature; the rural exodus persisted and by the end of the decade producers from these regions were looking to organise in unions different to the traditional ones. These issues were the main focus of working teams within the state.

The Federal Council of Investments (CFI) hosted interesting research teams that produced robust reports of the Argentine North-Eastern region, among other names let us remember sociologists such as Daniel Slutzky, Victor Brohderson, Gustavo Tesoriero, who worked on the productions of cotton and tobacco.

Another cluster of work took place within the Group of Rural Sociology of the Department of Agriculture and Cattle where, from 1969 and until 1976, a group of sociologists, economists and agronomists began a series of publications about small producers and agricultural workers in the northern regions. Some of the sociologists that participated in this group, that continue to be present in academic rural studies, are Susana Aparicio, Mercedes Basco, Norma Giarracca, Diego Piñeiro y Susana Soverna. 
The Department of Economics of INTA Castelar was developing the programme Information System for the Supply Plan of Products and Inputs of Agricultural Origin (SIPNA). It consisted in the description of productive systems, with the aim of planning production based on markets.

To these empirical works, that contributed to generating an abundant and qualified information on the sector, we should add others with research addressed from a theoretical and historical perspective. In that sense, CICSO was home to a significant number of sociologists, anthropologists, historians and economists that contributed to the analyses of the agrarian social structure, the regional unbalances and the class structures. In these issues we can locate the following authors: Oscar Colman, Alfredo Pucciarelli, Nicolas Ińigo Carrera, and Mercedes Basco. Them, like many other participants of the seminars, benefited from the classes and group discussions coordinated by Miguel Murmis.

The debate over the viability of the small family exploitation brought together studies from Social Anthropology. Many of the works on the issue were presented in a congress of the Association of Agrarian Economy, in the province of Tucumán, during 1974. In this direction it is worth mentioning about the issue the studies from Hebe Vessuri, Esther Hermitte, Carlos Herrán and Leopoldo Bartolomé. Simultaneously, another important anthropologist, Santiago Bilbao, along with a group of agronomists, were conducting the task of organising and accompanying the functioning of the first cooperative of agricultural production in the country: Campo de Herrera, in the province of Tucumán. This initiative that, early on, articulated theory and action, was supported by the technical expertise of Engineer Roberto Feernandez from Ullivarri and by the valuable intellectual production of Bilbao on issues of peasants and rural labour.

Even if the working conditions of agricultural labour were studied, it did not include as many technicians and researchers as that of small agricultural producers. From the classic work of G. Gallo Menoza and J. Tadeo, Labour in the agricultural sector, studies were developed on the precarity of rural employment (Rural Sociology of SEAG), migrations (Carlos Reboratti, Cristina Sabalain, Mario Margulis), the deficient labour conditions and seasonal work (Hebe Vessuri, Nicolas Ińigo Carrera, Floreal Forni).

Neither did the study of the union of agricultural sectors issue received exhaustive attention. However, it is worth mentioning works such as that of Liliana Kuznir and Nidia Margenat, about the Agrarian Federation, and those by Francisco Ferrara and 
Leopoldo Bartolomé, about the Agrarian Leagues. The search for an interpretation of the political phenomena of the sector did not have many adherents during those decades. The work of Francisco Delich about the study of social and political struggles of sugar cane peasants in Tucumán, published as Land and peasant conscious in Tucumán, attempted to link the economic conditions and the structural position of the small agricultural producer with their Peronist political identity. Lastly, we should remember a study about the pre-political forms of organization by marginalised sectors of the poor areas of the countries, Isidro Velasquez, prerevolutionary forms of violence, signed by the sociologist Roberto Carri. Influenced by the analyses of the time, specially by Eric Hobsbawm and Franz Fanon, he linked the "social vandalism" of the countryside in the Chaco region with the conditions necessary for radicalised political action.

In this period there were three other publications that I have intentionally left to address in a particular way because, in my opinion, they synthetizse significant theoretical debates and allowed to open up the conceptual discussion about highly relevant issues. The first was a work directed by the sociologist Miguel Murmis that was known as the study about marginality and that originated several articles from the issue 69/2 of the Revista Latinoamericana de Sociologia from the Di Tella Institute and in other following issues of the same journal. These publications started from the theoretical formulations of Marxism and discussed the validity of certain concepts for underdeveloped realities. But the theoretical debate was accompanied by extensive empirical studies about the north, about different productions and social actors, that marked a highlight in the style of works in the field of Rural Sociology in our country.

The second publication to which we refer to is that of E. Archetti and K. Stölen, Family Farming and capital accumulation in the Argentine countryside. This work recollects the contributions of Russian economist Alexandre Chayanov, discusses the concept of peasantry and, through fieldwork in Santa Fe, characterises the argentine colonist and conceptualises them as a family business susceptible of conduct a process of accumulation, which would differentiate it, according to the authors, of peasant units of production.

Lastly, the book by Guillermo Flichman, The soil's rent in capitalist development synthesises the academic production of the period. He used large part of the information available for different regions of the country and, supported by the theory of rent, interpreted the forms taken by capitalist development in the Argentine 
Latin America, New Ruralities | 124

agricultural sector. While this work was published in 1977, outside our country, we consider it a "golden end" to a period that, even if it had many shortcomings, left an important contribution to the study of the agrarian issue.

\section{Third period: 'Process' (1976-1983)}

The social and political context in which this period was developed was characterized by the unusual concentration of power that allowed the implementation of policies which implied profound transformations of society. The opening of the national economy to international competition, the financial policy that aggrandised this sector and the debt crisis of several economic sectors, to name just a few of the economic policies of the "juntas", were implemented along with the strongest and most systematic social and political repression of Argentine history.

In what pertains the agricultural sector, this period sees a significant jump in production of certain products of the Pampas, a process that was known as the "agriculturalization" of the Pampas region. This change occurred at the same time as the expansion and transnationalization of the input industry (seeds and agrochemicals), and a significant change in productive systems. The regions outside the Pampas also underwent considerable changes, such as the expansion of products and capital investments from the Pampas, support to new export products and the emergence of new social agents.

But let us see what happened during these years in the centres and institutions where studies on the agricultural sector was taking place. In the university, the modules that had been consolidated in the previous decades disappeared. It is important to point out that, even if this was a process that began in the last period of the government of Isabel Perón, it was accelerated and culminated with the military government. The School for Graduates in Agricultural Sciences that worked in INTA-Castelar was closed, the working groups inside the State apparatus were disarmed, both in INTA as in CFI and the working group on Rural Sociology at SEAG, and the Agrarian National Council was eliminated. The outlook would not be complete without mentioning the persecution, disappearance and exile of several specialists, as well as the disappearance, death or exile of union, social, and political leaders of the agrarian sector.

After the height of violence, there was a transition period in which there was an attempt to continue or begin some lines of work and research. They were attempts 
to keep contact and discussions going among professionals that remained in the country, to which aim there were internal seminars or small meetings. They tried to share the bibliography that was available from abroad and to build environments of discussion and reflection.

In the Group of Rural Sociology of SEAG, after the disassembling of the team that had been working together since 1969, a small group began to regroup and began a study on the mini holding in different regions of the country.

The Centre for Studies and Research on Labour (CEIL), an Institute belonging to the National Science and Technical Research Council (CONICET), was a place for regrouping of sociologists that had worked in other centres and that, directed by Floreal Forni and with the support of scholarships and subsidies from the Council, provided interesting studies about regional labour markets, labour conditions, female and child labour, and about machinery contractors in the Pampas Region. Rural sociologists that today have prestigious academic or professional positions took advantage of the scholarships and the right environment (exceptional for that time) to complete training and postgraduate degrees. The Centre for Social Science Research (CISCO) was developing historical research and retook a line of analysis of the social structure.

In the meantime, the Argentine Institute of Development (IADE) organised seminars with the participation of those who attempted to follow the debate about the agrarian issue.

In this reminder, that attempts to highlight the effort by social scientists that remained in the country to maintain open the possibility for thinking and debating, we should also point out the role played by the seminars and the journal Desarrollo Economico of the Institute of Economic Development (IDES), the tutorial course in the Latin American Faculty of Social Sciences (FLACSO) and the group that was known as the Centre for Agrarian Study and Promotion (CEPA), a place of encounter and debate for sociologists, economists and agronomists settled in different regions and with diverse or little institutional affiliation.

From 1981-1982 there was an identification of the need and possibility to increase open exchange, to integrate to theoretical debates in other countries, and, particularly, to update the bibliography. An important event in this sense was the $\mathrm{V}$ International Congress on Rural Sociology that took place in Mexico in 1980, where 
Latin America, New Ruralities | 126

specialists that remained in the country reconnected with their colleagues spread around the world.

From that point onwards, seminars and courses had more participants, fieldwork was conducted again, there were studies in different modules in universities outside Buenos Aires (Rosario, Comahue, Posadas). In these spaces the lack of human resources forced a fruitful interdisciplinary integration, because the challenges of the time required to privilege the analysis of the issue over the academic specialisations. In the National University of Rosario (Universidad Nacional de Rosario), for example, through an agreement with national and provincial agencies, the sociologist Silvia Cloquell began a work around the technical change in producers from the Pampas that was done with agrarian engineers.

During these years, some researchers continued to develop their research in social issues, in private centres with funding from international agencies that allocated special funds to Latin American countries suffering from repressive regimes. Some of these centres also explored the agrarian issue. In the Centre for Social Research on State and Management (CISEA), through a series of studies conducted by Jorge F. Sábato about the Pampas region, a team was composed that in the last period of the "process", began a complete analysis of the transformations of the Pampas agriculture. This group was directed by the economist Martin Piñeiro and brought together several researchers that had returned to the country.

Also CEUR worked on regional issues, while in the Centre for Population Studies (CENEP) geographers, economists and sociologists began works on the different regions of the country. Lastly, during that time, the Centre for Education Research (CIE) incorporated the rural issue through the educational problem, using an interesting and novel methodological approach: participatory research.

The research from these teams began to be published and diffused when our country began to once again go through the Constitutional avenue and are in the bibliography of this article.

\section{Fourth period: A return to democracy (1982 - until the present)}

In December 1983, us, Argentines, we recovered through elections the hope of recreating a citizenship that had been lost during the dark years of the "Process". The erosion that the war with the United Kingdom generated, the economic recession, 
international pressure and the important role played by human rights organisations, were some of the elements that persuaded the military government to call to national elections. President Raúl Alfonsín governed a country where, with time, the structural changes that were foreseen in the previous period would unfold, and would give the thorough meaning to the terrible repression initiated in 1976. The economic recession, the external debt, the change in property relations, the beginning of the hegemony of the neoliberal narrative, the transformations in the labour world, provoked - not only in this country but in all of Latin America - what ECLAC called "the lost decade".

Regardless, and almost paradoxically, the agricultural sector had been growing in an uneven and unequal way. Some subsectors increased their production due to new technological packages and changes in the orientations of the market (they began to export). Others, generally linked to the domestic market, stagnated and decreased their levels of activity. The boom in cereals and oilseeds was taking place due to the production of five crops from the Pampas. From the 1980s, the heterogeneity of growth was clearly evidenced when analysing the increase of the subsectors and the evolution of relative participation of each of them.

In general terms, the changes in productive levels was taking place, basically, due to the success of the soybean complex and production linked to the vegetable oil industry as well as export products. As for the regions outside the Pampas, certain crops grew, particularly: dry beans, apples, rice, tea and tobacco for export markets. In the last years horticultural and citric production grew.

But the most important changes were given in the social structure of agriculture, a situation that was reinforced with the decree of deregulation during the government of Carlos Menem, towards the end of 1991.

Towards the end of the 1980s, small and medium producers around the country began to feel a series of economic measures with a strong tendency towards concentration, that would unfold with mighty force during the 1990s. Taxes increased, services were privatised, financial costs went up, etc. A large part of the sector was accumulating debt, and even associations of indebted producers began to organise scared for their properties.

Simultaneously, mid-decade, other forms of facing production were beginning to emerge, with different forms of acquiring capital. Two mechanisms were present: investment funds and planting pools. Producers would give their lands to these 
organisations that would deal with production attempting to manage at a large scale both the purchase of inputs and the selling of the produce. Moreover, they were exempt from paying the fixed costs of the farm and the maintenance costs of local administrations.

The differences among investment funds were significant: they could be groups of producers getting together for one or two seasons, or investments from capitals external to agriculture, or large investments with consultancy companies and banks in large scale operations. Faced with these more developed systems, some researchers fear a significant concentration process, but others believe that inflow and outflow of capital to the sector would not end in important changes in the property relations. Regardless, there are also large capitalists that purchase large extensions of land (Soros, Benetton, etc.) and the formation of "economic groups" is noted.

A possible division in the period, in the framework of the agrarian processes, would be in 1991, when the government of Carlos Menem, through a decree of necessity and urgency ended with the whole institutional network that had supported the agricultural social structure since the beginning of the century. In my opinion, during these times at the end of the nineties, the argentine agricultural sector is going through, with certain delay, changes as deep as those experienced by the rest of the Argentine economy.

The so called "regional economies" suffered the impact of deregulation, the emergence of "markets" in regions crossed by traditional local powers, with the capacity to influence the national government through the political party apparatus and legislators, is not simply an 'economic' situation as it is sometimes proposed. Those who suffered the most with the regional changes were rural workers and peasants. The unemployment rates of the provinces affected by these austerity measures are high, and subsistence settlements are also found in provinces which would provide rural labour.

Faced with these circumstances, the state, advised and financed by international organisations, began to design social programmes that would address the increase in levels of rural poverty. This is the time for support to small producers, the Agricultural Social Programme, and the management and implementation of a big programme financed by the World Bank oriented towards the most vulnerable sectors (PROINDER). 
On the other hand, during the open period in 1984, there was a recovery of university spaces through entrance examinations and the generation that had remained in exile during the previous period returned to the country, who joined the professionals that had remained here. However, neither the university system nor the scientific one provided the conditions for social scientists to settle and remain. The low salaries, lack of entrance examinations, the fallback of CONICET after 1989 and all kinds of difficulties that emerged in universities, where the reasons that lead many people in Social Sciences to work as consultants in international organisations or nongovernmental organisations.

In many cases they did both - working in universities or in CONICET and doing consultancy work - which, in my opinion, deepens an interpretation of discursive styles that has been recurrent in our disciplines.

On the other hand, private research centres continued to work until 1989. From then on, the external support and those received by the UCR government were withdrawn; some moved to University of Buenos Aires (CISEA; CEUR), others were transformed into consultancy companies (CEDES and CEPA). The exception was FLACSO, which went through a period of crisis during the first years of democracy towards one in which it received larger support and remained as a centre for postgraduate studies and research. Simultaneously, the Fundación Banco Patricios, University Di Tella and several universities in the suburbs of Buenos Aires opened their doors.

Lastly, there are non-governmental organisations (NGOs), that had different behaviours during these years. The one that had the biggest impact during the first democracy years (as per our analysis) was Compared Interdisciplinary Studies of the Andean Region (ECIRA), which later became the Andean Centre of Research and Education (CADIF). The novelties that ECIRA brought were organisational as well as the articulation that was established with UBA. In fact, it was a research and development programme financed by Italian cooperation that provided different results. In its first period, it was directed by anthropologist Alejandro Isla, who imprinted a very particular style; it was an UBA programme installed in Jujuy that provided material of intellectual rigour. Moreover, he created a development programme in the Valley of Amaicha (Tucumán), even if, while conducting this, the group was not able to overcome the difficulties and conflicts that this type of interventions usually entail.

During the first years, ECIRA/CADIF published, in my opinion, one of the most achieved attempts to bring together action and Social Theory: Andean North. This 
was a magazine with excellent illustrations that combined interviews and life stories with interesting reflections, bringing the debate to social actors in the Argentine North-West. Only seven issues were published, but the experience marked a working style that, unfortunately, was never reproduced. Later, CADIF, no longer with affiliation to UBA and with a different direction, changed its working style and was transformed into an NGO with a functioning that resembled more those organisations.

Together with CADIF, there are other NGOs linked to the rural sector and the environment, with uneven production of material, as relevant to our objectives. Several of them are strongly connected with the Agricultural Social Programme (PSA) from the Department for Agriculture, Cattle, and Fishing (SAGPyA) (the most important social policy for the agricultural sector from the Menem government), due to the fact that PSA is run by a technocrat that emerged from said sector. The material produced by this sector, with some exceptions, circulates in a restrained way and it is probably the most under-represented group in the annexed bibliography.

To sum up, the material on agrarian and rural studies from this period is dispersed, in large amount unpublished, and, consequently, has a limited distribution. It is worth asking if these conditions emerge from the lack of interest on the issue by the whole of the Social Sciences or the lack of organisation from disciplinary communities (journals with unpredictable publication patterns, few seminars and congresses, etc.).

In the previous paragraphs I highlighted several centres or offices where relevant material is produced and saved. We can sum this up:

- Research programmes in national universities; they can include postgraduate taught degrees and, consequently, the production of masters' theses or simply the production of the research teams with researchers and students; in recent times doctoral thesis were also included. In this category we will also include CEIL, because even if it is not a university centre, it is financed by the state (CONICET) and most of its members are university teachers.

- Private research centres that worked until recently or continue to work.

- International organisations and state agencies that require from consultants' socio-economic works to develop public policy.

- Non-Governmental Organisations dedicated to development programmes in rural areas. 
The rigour and academic quality of production is not necessarily the product of any of these places in particular. However, research with production of data were paradoxically more frequent in universities and in CEIL than in other institutions. I argue that it is a paradoxical situation because even if universities have been poorly funded and, at the same time, have dedicated a very meagre percentage of their budgets to research, teams based there conducted expensive fieldworks.

The different methodological-theoretical perspectives that we can find by reviewing part of the material, have much to do with the themes covered, since, unlike with previous periods, there was more thematic diversity linked to new analytical perspectives. This organisation, that explores issues and analytical perspectives at the same time, produces an eclectic result, with non-exclusive categories when it refers to authors. However, I present it this way as much as it allows to link the new debates of the period with the new methodological-theoretical contributions. In my opinion, this thematic diversity and theoretical flexibility is the main characteristic of the period and what I intend to highlight.

1. In the first place there are those studies that persist in their structural perspective. They try to note the changes in the productive and socio-economic structures of the sector. Previous works hierarchised land, property, tenancy and levels of capital; the new ones recovered the role of institutions, public policies, and, in some cases, focused on the social relations that these structures were holding. The influence of new trends in French regulationism and the renewed contributions from Political Economy provided more complexity to this kind of works. At the same time, many were produced under the influence of neoliberal economic models, especially those of international organisations.

Within this first type we can situate the studies conducted by the research programme that, at the beginning of the period was directed by Martin Piñeiro and then by Osvaldo Barsky at CISEA. This programme attempted to identify the changes in the Pampas region up until the 1980s, focusing and searching for explanations in the technical sphere but without dismissing other socio-economic issues that allowed the productive jumps of the time (see the three publications compiled by Barsky, 1988).

In that same direction other works can be included, also about the Pampas region, elaborated by CEPA (see CEPA, 1983 and 1990), that allowed an interesting debate about the socio-economic trends that marked the productive changes. Researchers at CEPA, unlike those at CISEA, held that the institutional-economic tendency 
Latin America, New Ruralities | 132

indicated that the small and medium far was in risk of disappearing, while others highlighted the "farming" characteristic of the agricultural process.

During our time, at the end of the period, the debate remains but now among researchers within the same research centre: FLACSO. Indeed, Osvaldo Barsky (coordinator of the Rural path in FLACSO's Master's degree), along with Alfredo Pucciarelli and Mario Larruada keep an interesting debate about the concentrating trends in agriculture with Eduardo Basualdo, from the economics department of FLACSO (see the debate in Realidad Economica, N. 134, Vol 34.). Once again, while Basualdo crates and organises new data and checks that, at the level of property relations, concentration of land is continuing, Barsky continues to assert that there are no tested tendencies about the disappearance of the middle sectors (based on census data). It is interesting to point out that this debate, that began with the break of dawn of the recovered democracy, continued throughout the period. It was expressed in articles and seminars that brought together scholars of the field. In that sense, the most memorable one is that organised in 1993 at the Faculty of Social Sciences at UBA and which was called "The Argentine agro, today" (remembering that of 1985), where researchers participating in this issue were protagonists of an energised debate.

Most of the technical reports written by consultants for SAGPyA are located in this structuralist perspective and were conducted by agronomists, economists and sociologists. Generally, they diagnose certain productions, regions, or socio-economic problems. Of the long list of reports of all kind created in this institutional framework, and published in Agricultural and Fishing Statistics, of the Department of Agriculture, Cattle, and Fishing, Sub-Department of Agricultural Economy, in 1994, I have selected and included in the general bibliography those reports signed by authors who are experts in the socio-economic areas, with academic background. That is, I tried that the works cited keep some of the rules of intellectual work appropriate to Social Sciences.

In general, these works are of technical character, descriptions and diagnoses of production, commercialisation, financing problems, etc. Among the authors are specialists with long careers in rural studies such as economists Edith Obschatko, Juan Ińigo Carrera, Sergio Levín, María del Carmen González, Graciela Gutman, etc. There are also sociologists such as Mercedes Basco, Ignacio Llovet, María del Carmen Borro, Susana Soverna, Clara Craviotti, Roberto Benencia, etc. 
There is another group of works, that we situate within this first category, that created typologies or took for their characterisation a particular socio-economic sector (peasants, rural workers, etc.). All of these put emphasis in the transformations of the economic scenarios to the sectors where they act, assigned to the modifications of a social regime of accumulation that occurred during the 1970s.

We situate here the creation of typologies of producers defined before and after the Agricultural National Census of 1988 with the purpose of identifying changes in the agrarian structure. In general, these were research projects on the social structures that complement the structural position of the producer with other analyses that highlight the capabilities of actors that cannot be explained from structures (see IPDERNOA, 1992, and Giarracca and Aparicio, 1991).

There are also the works that focus on a particular type of producer: the peasants, capitalised family farmers, etc. For example, the analyses about 'contractors' conducted by Ignacio Llovet in the CISEA team; publications with this same orientation in CEIL; works on peasants written by economists or agrarian engineers (Mabel Manzanal, Raul Paz, Petro Tsakoumagkos, etc); works about family farms by sociologist Silvia Cloquell and those written by researchers at the National University of Misiones.

A decade ago there was a debate about the attributes that characterise small producers such as peasants and their relative importance in the agrarian social structure (see Giarracca and Manzanal, 1990).

Lastly, in this group I situate the studies on rural work that are linked to networks of labour studies (ASET) that have a great influence from the French regulation school. These studies present strong links between the "accumulation regimes" and changes in the labour world (see works on labour from CEIL in Bibliography, particularly Forni, Benencia, Neiman and Aparicio, 1988; Benencia, 1992; Benencia and Formi, 1996)/

To sum up, in all of these works the logic of changes is navigated in the deep restructuring that our society experience since mid-1970s. Without neglecting the external trends, the emphasis is on those who receive such tendencies and how they do it, without drifting away from their structural positions. Generally speaking, these studies have a great amount of secondary information and creation of quantitative data. 
2. In the second group I situate those sources that have emphasised in their analyses the structural relations but those conditioned by trends that go beyond national borders. They can have as a starting point structuralist approaches, but they are characterised for proposing the national issue as 'cases' of international trends. While in the first group theoretical assumptions are strongly connected to internal social dynamics and forces, here the issue is observed from the perspective of an increasingly interconnected world.

During the previous period it was frequent to find authors that proposed the limitations that agribusiness presented as a form of organisation in the argentine countryside. During the 1980s, evidence was beginning to show the impact of agroindustrial expansion around the world. Our country could not escape these trends given the neoliberal policies that were being implemented. We locate in this category studies that were constructing the issue of agro-industrial expansion, the agrifood system or linking local phenomena with globalization.

From these approaches it is possible to analyse a particular agro-industrial system, but there is always a pre-existing set of conceptualizations (assumptions in the sense of Alexander, 1997) that lead to new ways of looking at the agrarian sector, much more linked to (articulated with) both the rest of the economy as well as to the globalized economy.

Miguel Murmis, in his article "Some issues for discussion in Latin American Rural Sociology: re-structuring, unstructured, and problems of excluded and included", of 1994, argues, as the Brazilians do, that it is possible to talk about the 'qualification' of agriculture, as a new way of analyzing agriculture, not like a sector, but like the scenario for articulations with the rest of the economy. From these perspectives, it is important to analyse both those who enter as well as those who are excluded of these processes of agro-industrialisation.

Among this second group of studies we can situate both economists and sociologists and geographers that early on began to propose the incorporation of Argentina to the strong agro-industrial expansion happening at the world scale. The work by economists Miguel Teubal and Graciela Gutman was pioneer in this trend. Both authors had worked with methodologies of agro-industrial and agri-food complexes and systems in Mexico and Venezuela, respectively, and applied them before anyone else in our country (see Gutman and Gatto, 1990, and Teubal, 1995). 
Simultaneously, sociologists and geographers contributed to these studies proposing a focus on relations, conflicts and negotiations among unequal actors within the space of CAI.

We can mention, among these lines, the studies that were conducted about the fruit agro-industry in the Río Negro valley conducted by sociologist Monica Bendini and her collaborators; by the geographer Gerardo De Jong and the economist Ernesto Bilder, all of them researchers of the National University of Comahue. There are also the works about agro-industries in North-East and North-West Argentina - rice and sugarcane - conducted in a first period by Susana Aparicio, Norma Giarracca, Susana Soverna, and Maria Isabel Tort within CEPA. We can also find a programme coordinated by Alejandro Rofman in CEUR that studied agro-industries and that in recent times continues their analyses incorporating the impact of Mercosur.

A team of the Faculty of Agronomy has also incorporated the changes that MERCOSUR creates in the rice industry (Lilian Pagliettini). Moreover we find the work on beer barley by Teubal and Pastore and on the poultry complex from Patricia Davalos (see all of these authors in the general Bibliography).

Graciela Gutman conducted agro-industrial studies as consultancy works for SEAGYP, introducing these methodologies in the technical report of the public sector (Gutman and Rebella, 1989).

Moving into the nineties, agro-industrial studies generated the enthusiasm of young researchers trained during this period and that began to systematise and comment the works conducted through the 1980s (see Martinez IBarreta, Pucciarelly and Posada, 1994).

Within the agri-food issue we can include, besides the contributions by Teubal and Gutman, those of Graciela Ghezan and Monica Mateos from the National University of Mar del Plata (see Ghezan and Mateos, 1994). During the last years, from different institutions, a series of publications emerged about the horticultural activity, that included elements linked to the food problem, with new forms of agricultural organisation emerging from the Bolivian migration, etc. (see Benencia, 1997). These studies also contained a lot of secondary information and creation of primary quantitative information. Moreover, there is a great comparative component in their analysis due to the fact that, as we mentioned before, the methodology of "agroindustrial systems or complexes" is applied with few variations for different productions and in different countries. Moreover, sociologists and anthropologists 
Latin America, New Ruralities | 136

incorporate qualitative data that brings the readers closer to the social worlds of the actors being studied.

3. The impact of the crisis and the turns of social theories after the 1970s were lesser on Rural Sociology and Anthropology that they were in other thematic fields (Political Studies, Cultural Studies, for example).

In this third category we will include all of those works that identify these impacts in different ways and degrees. In general, these are interpretative studies, with more emphasis on "understanding" than explaining, which means a different place for the researcher. Indeed, the understanding of meanings that subjects produce is, basically, a communicational experience and requires the participation of the researcher and of someone else to produce it.

In these studies the search for "actors", "agents" capable of producing senses, representations of the social world to which the researchers is no stranger to, is identified. It is no longer the "structure" what provides intelligibility to relations and processes, but social reality is conceived in terms of symbols (e.g. signs and representations), which meaning (e.g. sense and value) we want to understand.

The material that is included in this category is due to the work, basically, of anthropologists and sociologists. On the other hand, even if with certain slowness, political scientists are approaching rural studies and we know of at least one contribution from this perspective. In general, these types of studies require fieldwork, of certain ethnography capable of getting the reader closer to the social worlds and lives of rural populations. However, it is also possible to work on scenarios with the participation of actors that generate conflicts, negotiations, arrangements, with journalist sources, texts (declarations, adverts, etc.). A good example of a mixed handling of material is the work by political scientist Jose Nun in an essay, from a few years ago, on the milk agro-industry (see Nun and Lattuda, 1991).

In general, a good part of anthropologists and sociologists are working from these perspectives. The references to the theory of action, to Anthony Giddens or Pierre Bourdieu are no longer an exception in rural studies. The works by British anthropologist Norman Long in the University of Wageningen, Netherlands, contributed to consolidate what was known as "the actor's perspective". The outlook began to be positioned on actors and their actions; concepts such as "family strategies", "collective actions" began to circulate.

The new social movements of wives of indebted producers or others that ended in union organisations or cooperatives, also sparked the curiosity of researchers. The rural woman and the expansion of the struggle over rights, over space in democracy 
for ethnic minorities (Mapuches, Kollas, etc.) were opening as themes in these methodological theoretical perspectives. Issues such as culture, ethnic, gender, or social identity, are explored by sociologists and anthropologists. The questions of biculturalism as facilitator or obstacle to economic modernisation circulate, not only on academic spheres, but also among NGOs. Moreover, this approach aims to open up space among debates on "rural development" where structuralist views are still dominant.

Academically, these perspectives allow young sociologists and anthropologists, trained in careers where new social theories prevail, to become interested in rural studies and develop their work in these areas. I situate within this category the previously cited work by Nun, those by the Research Programme coordinated by anthropologist Mauricio Bovin of the Faculty of Social Sciences of UBA and University of Paraná, the work by anthropologist Hugo Ratier, researcher of the Faculty of Philosophy and Literature of UBA; works about transformations of family fruit farmers in Rio Negro conducted by an interdisciplinary group (that includes a philosopher) of University of Comahue. I also include our own work about collective action in the rural world (Rural Study Group of Institute Gino Germani); theses and essays from the Postgraduate Programme of the National University of Catamarca, particularly those by anthropologist Cynthia Pizarro. There are also the works by Jose Luis Grosso, the anthropologist Alejandro Isla, and the contributions by Silvia Cloquell about the environment from an actor's perspective.

Young researchers in programmes and working groups mentioned earlier have written postgraduate thesis and research reports that are particularly good examples of these new perspectives on the agrarian social worlds (see Cynthia Pizarro, Fernando Balbi; Valeria Hall; Inés Alfaro; Paula Gutiérrez, Leandro Bertoni, among others). The use of "life histories" helps to understand the life and worlds of the social actors that are protagonists of collective action (see Bidaseca, 1998).

These "understandings", in many occasions complemented structural analysis with quantitative data (triangulation). These interesting combinations emerged generally in works of sociologists Floreal Forni, Roberto Benencia, Guillermo Neiman, Susana Aparicio, Carla Gras and in those of almost all who use interviews with actors involved in their research. Not always does the use of interviews lead to interpretation of the researcher, as they can also appear as examples or testimony of something that is argued from the data. 
4. I wanted to establish a residual category, much more eclectic than the previous ones, that includes topics that refer to problems that have aggravated in recent times. I am referring to studies on poverty, the rural woman and the environment. In effect, the significance of these issues generated more interest by those studying during the 1990s that are in search for theoretical-methodological approaches that contribute to a rich analysis and of how to institutionalise them in academic fields. Here, it is not possible to establish links between "themes" and "approaches" because in the approaches to these issues we find positions that are both structuralist as interpretivist.

In fact, on the issue of rural poverty, Miguel Murmis has not only contributed theoretically as well as rigorous data analysis (see Murmis, 1996), but he brought together an interdisciplinary discussion in a special session during the Congress "Poverty and the poor in Argentina" that took place at the end of 1997 in the National University of Quilmes. In this session papers were presented on rural workers, poor peasants, migrants, workers with multiple jobs, and it was proposed to create a network on the issue.

The topic had been studied a few years before by the economist Mabel Manzanal, who published a first diagnosis about the problem in 1993 in Strategies for the survival of the rural poor.

As it was mentioned before, on the issue of rural poverty there is a particular interest from the World Bank, which develops a programme (PROINDER) within the Secretariat of Agriculture. Within such programme there were important reports written that compiled the studies on poverty and the rural poor and that provided a good synthesis from very useful categorisations (see Craviotti, 1995, Soverna, 1995, Benencia and Karasik, 1995).

From a political economy perspective, Miguel Teubal links poverty with both the accumulation model, and particularly with the income distribution, as well as with the agri-food system that modified substantially the conditions for access to food of large social sectors.

On the gender issue, the contributions come from sociologists and social anthropologists as well as historians and agronomists. During the Seminars "History of women and gender studies" that usually take place in the Centre of Gender Studies, very interesting interdisciplinary debates take place. Because the published work is sparse, in the general Bibliography I have included namely those works presented in the last Seminars, even when other works presented in earlier seminars which are significantly less. The work by Cristina Biaggi, The woman as agricultural 
producer in Argentina, presented in the last seminar at the National University of Tucuman in 1996, provides a general overview of women's work in the countryside through the analysis of census data of 1988 . We can also find works about the role of women in discourse around the modernization of the Pampas, about the health issue, female peasants, etc.

Besides these studies, there are articles published with a gender perspective that attempt to address the subordinate position of women both in the workplace as in the family setting (see Basco, 1992; Racedo, 1988; Bravo and Garrido, 1993; Giarracca, 1994 and 1998; and Bendini and Bonaccorsi, 1998).

The environmental issue generated the interest of economists, geographers, and sociologists, either if it is taken as a central issue, or as an aspect to be considered in general studies. Teams directed by geographer Carlos Reboratti in the Faculty of Philosophy and Literature (UBA) and by sociologist Silvia Cloquell in National University of Rosario created some interesting work. In fact, Carlos Reboratti knows how to bring in his analysis other disciplines relevant to the issue but without forgetting that the 'problem' is the relationship between men in society with nature. In that sense, the contributions by biologists and ecologists with whom he works provide content to these studies without losing, overall, the 'social perspective'.

On the other hand, the work by Silvia Cloquell demonstrate the richness of the "actor's perspective" in these issues. They demonstrate how the logics of the decisions made by producers, in connection with the environment, are constructed from their social and economic conditions. In that sense, the proposal by Cloquell is very useful to complement the visions of "ecologists" as social actors.

The studies by economist Pedro Tsakoumagkos puts certain limits to the radicalised positions of an ecological Political Economy and contribute to the question of environmental impact assessments in development projects (see Tsakoumagkos, 1988 and 1992). Lastly, there are working teams directed by biologists or ecologists that introduce social perspectives in their analysis but, because of disciplinary issues, I did not take into account for this bibliographic organisation.

Finally, I should point out that I regret to leave out the work of historians that, in one way or another, is present in the previous ones. To include them would have involved a work in itself, since I consider historiographic work since 1984 to be of a higher fertility as that of other disciplines. Nevertheless, it is important to point out that contemporary historians changed the images of agrarian processes in this country 
and, as a result, contributed to change the questions of the present. Regardless, many historians that have helped me, in my role as a teacher and researcher, to think of the development of the Pampas and the construction of the rural society of Tucuman, are included in the general bibliography.

\section{Some final thoughts}

During the century that is ending, both social thinking and Social Sciences, institutionalised after the 1950s, were attentive to the big agrarian problems of each period and participated in their debates.

And this is not irrelevant, as a conclusion, if we consider how were the conditions for the production of thoughts, ideas, and debates during this century that is ending. The tension between "democracy-authoritarianism" or between "institutionalisation - lack of funding" ran through the spaces of creation of social thinking of the past century. Many excellent studies were never published, or re-edited, or translated (like that of Taylor).

However, as we have seen in previous pages, the issues relevant to agricultural production, to development, or to the life of people, have been explored, even if only by a small group or few people. The possibilities of diffusion and circulation of these studies is another problem and deserves to be considered within a broader construction of a Sociology of Social Sciences.

These last lines address the impacts of Rural Studies in the social construction of economic, social, and cultural worlds of the Argentine countryside. And the question can be presented if we take a "constructivist" theoretical perspective of the social world. That is, if we begin from the point of recognising our participation as social actors in the university, as technical specialists, in the state, or as members of development programmes in the social construction of rural worlds, then we will understand the meaning of the question. The studies organised and presented in this article were not, according to this perspective, ignorant of these constructions.

In relation to the institutional affiliation of authors, several aspects contribute to this position: they circulated through different environments - universities, state offices, international organisations - and did not find significant differences in discursive style or the proposals generated in one place or the other. It is not possible to seriously argue that there were discussions external or marginal to these institutions. 
Several of the authors cited in the text or appearing in the bibliography were (or are, today) in decision-making roles in agrarian policy: Horacio Giberti, Lucio Recca, Felipe Sola, just to name the most recent ones. Sociologists, anthropologists, and geographers participated in the creation of public policies, design of censuses, or in development programmes. With the restrictions proper of any period of repression, many of us went through, at some point, the spaces of public administration. Most of the "agrarian" authors debated, in general terms, within "modernising" positions, that proposed the introduction of technologies that would incentivise higher productivity, a business logic, public policies to improve credit, working conditions, and markets for small producers, etc.

The main debates at the beginning of the century can be summed up with the following questions: How can we create amazing agricultural development to include the middle sectors and workers? What general policies are limiting development? In the following years the debate created by Taylor circled around the possibilities of extending the farmer model and limiting the power of large landowners. From the 1950 s onwards the technological issue took centre stage.

With the institutionalisation of Social Sciences, the debates became more academic but always connected to the problem of development and its main actors. The issue around the landowner of the Pampas had strong political connotations and was pushed forward by intellectuals from different theoretical positions. But these debates did not correspond to situations of expansion in agrarian conflict.

And this is an important difference with other Latin American intellectual productions where you can find both radical positions as well as those that modified the 'common sense' around the normalcy of power relations. An example of this lies on the significance of the idea or concept "agrarian reform": for most Latin American countries this was already in the 1970 s a public policy like any other, incorporated to the language of 'common sense', while in our country it would translate as a measure that required a social revolution and it was almost a dangerous concept.

The agricultural processes and social structures of our country had characteristics that disincentivized radical theorisations of social change. First, the historical prevalence in numbers of an agrarian middle class; second, the political 'invisibility' of rural workers, that is, the failure in constructing a privileged social actor for change. 
Latin America, New Ruralities | 142

For positions with strong grounding on orthodox Marxism, chacareros and farmers, and the Argentine Agrarian Federation represented the "petty bourgeoisie" and were not interesting social actors for models of social change. Rural wage workers - even though they reached similar numbers to those of the Steel Workers Union - rarely led any collective action and were not considered political subjects to be studied.

For these reasons, the agrarian debates of authors in any of the critical theory variants always had as point of reference the "landowner from the Pampas" and their most political face: the Argentine Rural Society (SRA). However, as we have seen, there has not been any consensus around the role that this actor played in the capitalist development and almost everyone recognised its modernising role. Very few argued about SRA as a traditional, landowning subject.

To sum up, the relevant rural studies of this century were, both in numeric terms as in terms of their political impact, those elaborated from a "modernising" perspective (from any theoretical position).

The more "reformist" variants that incorporated social issues of farmers, peasants, and rural workers, had to open up space among the criticisms of positions influenced by the traditional left and the political opposition of those who held power. Some of our "authors" tried to demonstrate through thinking and through action that the 'modernising' and 'reformist' positions were not necessarily incompatible.

But some of those who tried to produce new theoretical-political views or to take on democratising reforms from the state or from agencies, like INTA, were marginalized or expelled from their government or university positions and suffered the repression of the 1970s: jail and exile. That is, to align with those who questioned the hegemonic order and tried to modify them "here and now", from the perspective of the social actors, had to pay, in our country, very high social and personal costs.

Today, unlike previous times, hegemonic neoliberal speech appropriated the idea of "modernization" giving it a single sense. The challenge for Rural Studies, that maintain critique as an essential element, consists in being theoretically superior to this fallacy and to articulate the idea of modernization with multiple and diverse avenues. The task is as complex as it was thinking about modernisation with social reforms in other times. The economic discourse is, for the time being, the one that shapes meanings and a linguistic assertiveness that turned "the only way out" into "common sense". But, as we saw during the fourth period, we have a diversity of studies and social actions that support the old idea of Pierre Rosanvallon of 
"experimental society", a world that is not finished and is always in transformation. The battlefield of knowledge, as was defined by Long (1992) takes on meaning in this image of the social that is not sown, it is open.

I would like to end this work with a recognition to the 'subjects'. During the whole article I emphasised the institutional conditions of production. However, the area of academic Rural Studies exists because of certain subjects more than because of institutions. In fact, I think that institutional weakness to develop Rural Studies during this century and even today, as been compensated with subjects that created it, from universities, public agencies, or modest research centres.

\section{References}

Alexander, J. 1997 Las teorías sociológicas desde la Segunda Guerra Mundial. Análisis multidimensional (Barcelona: Gedisa).

Alfaro, M. I. 1997 "Conflictividad social y nuevos patrones de acción colectiva: el caso de los campesinos santiagueños”, Informe final de beca de iniciación (Buenos Aires: UBACyT) mimeo.

Astori, D. 1984 Controversia sobre el agro latinoamericano: un análisis crítico (Buenos Aires: CLACSO).

Barsky, O. 1997 "La información estadística y las visiones sobre la estructura agrarian pampeana” en Barsky, O. y Pucciarelli, A. (comps.) La agricultura pampeana. El fin de un período (Buenos Aires: CBC /FLACSO).

Barsky, O. et al. 1988 "Evolución y rasgos actuales de estructura agraria pampeana" en La economía agraria argentina (Buenos Aires: Asociación Argentina de Economía Agraria / IICA).

Basco, M. et al. 1992 Trabajando con mujeres campesinas en el noroeste argentino: aportes al enfoque de género en el desarrollo rural (Buenos Aires: IICA).

Bendini, M. y Bonaccorsi, G. 1998 Con las puras manos (Buenos Aires: La Colmena).

Benencia, R. (coord.) 1997 Área hortícola bonaerense. Cambios en la producción y su incidencia en los sectores sociales (Buenos Aires: La Colmena). 
Benencia, R. 1992 "Características de la expansión capitalista en el agro pampeano”, tesis de Maestría (Buenos Aires: Flacso)

Benencia, R. y Forni, F. 1996 "Sociología y empleo agrario en la Argentina” en Panaia, M. (comp.) Trabajo y empleo. Un abordaje interdisciplinario (Buenos Aires: Eudeba / Paite).

Benencia, R. y Karasik, G. 1995 "Bolivianos en Buenos Aires: aspectos de su integración laboral y cultural” en Estudios Migratorios Latinoamericanos (Buenos Aires: CEMLA) No 27 , agosto.

Bertoni, L. 1992 "El Estado en el complejo agroindustrial tabacalero", informe parcial de Beca de Iniciación (Buenos Aires: UBACYT) mimeo.

Bertoni, L. 1995 "El complejo tabacalera y la intervención estatal” en Giarracca, N.; Aparicio, S.; Gras, C. y Bertoni, L. Agroindustrias del Noroeste, el papel de los actores sociales (Buenos Aires: La Colmena).

Bidaseca, K. 1998 "Los campesinos cañeros: construcción de una identidad” en Giarracca, N. y Mallimaci, F. (comps.) Movimientos sociales: acciones colectivas e identidades en transformación (Buenos Aires: Eudeba).

Bravo, M. C. y Garrido de Biazzo, H. 1993 "Aportes de la Universidad a los estudios de la mujer campesina den Tucumán: entre la crisis y la migración”, Jornadas Preparatorias para el Congreso de la Mujer en Berlín.

CEPA 1983 "La política económica y su impacto en las economías agrarias marginales (caso de algunas producciones del noroeste argentino en la década 70/80" en $\mathrm{I}^{\circ}$ Seminario Latinoamericano sobre campesinado y tecnología campesina (Punta de Tilcara, Chile).

CEPA 1990 “Transformaciones sociales en el agro pampeano" en Realidad Económica (Buenos Aires) N 92-93.

Craviotti, C. 1995 "Relevamiento y síntesis de estudios de casos sobre pobres rurales”, informe (Buenos Aires: SEAGyP /PROINDER).

Forni, F.; Benencia, R.; Neiman, G. y Aparicio, S. 1988 "El empleo agropecuario en la Argentina” en La economía agrarian argentina. Consideraciones sobre su evolución y situación actual (XX Congreso Internacional de Economistas Agrarios) (Buenos Aires: Asociación Argentina de Economía Agraria). 
Ghezan, G. y Mateos, M. 1994 "Las grandes empresas agroalimentarias frente a la integración regional” en Realidad Económica (Buenos Aires) N85.

Giarracca, N. y Aparicio, S. 1991 "Los campesinos cañeros: multiocupación y organización" en Cuaderno del Instituto de Investigaciones (Buenos Aires: Facultad de Ciencias Sociales, UBA) No 3.

Giarracca, N. (comp.) 1994 Acciones colectivas, organizaciones cooperativas. Reflexiones y estudios de caso (Buenos Aires: Centro Editor de América Latina, Bibliotecas Universitarias).

Giarracca, N. 1990 “El campesinado en la Argentina. Un debate tardío” en Realidad Económica (Buenos Aires) $\mathrm{N}^{\circ} 94$.

Giarracca, N. 1991 "Germani y su época” en Boletín de Ciencias Sociales (Buenos Aires: UBA-FSOC).

Giarracca, N. 1992 "Algunas reflexiones sobre las ciencias sociales y la investigación en los espacios académicos públicos” en Sociedad (Buenos Aires) $\mathrm{N}^{\circ} 1$.

Giarracca, N. 1997 "La acción social en los procesos agrarios y en el mundo rural”, presentación en Red de Filosofía y Teoría Social, 2o Encuentro, Universidad Nacional de Catamarca, Catamarca.

Giarracca, N. 1998 "El trabajo invisible de las campesinas tucumanas: un intent de reflexión” en Temas de Mujeres. Perspectivas de género (Tucumán: Centro de Estudios Históricos Interdisciplinarios sobre la Mujer, UNT).

Gutiérrez, P. y Roggi, M. C. 1998 "Sobre encuentros y desencuentros. Reflexiones acerca del trabajo de campo" en Giarracca, N. (coord.) Estudios rurales: teorías, problemas y orientaciones metodológicas (Buenos Aires: Eudeba).

Gutman, G. y Gatto, F. (comps.) 1990 Agroindustrias en Argentina. Cambios productivos y organizativos recientes (Buenos Aires: CEAL).

Gutman, G. y Rebella, C. 1989 “subsistema lácteo: elementos de diagnóstico para la formulación de políticas comerciales y tecnológicas”, borrador para discusión, primera versión (Buenos Aires: SEAGyP, BM).

IPDERNOA 1992 "Estadísticas básicas rurales y del sector agropecuario” (Tucumán: Instituto para el Desarrollo Rural del Noroeste Argentino, Universidad Nacional de Tucumán, Serie Investigación). 
Llovet, I. 1996 "Ensayismo y empiricidad: apuntes sobre las orientaciones de la Sociología Rural en la Argentina (1990-1996)", ponencia presentada al Congreso de Historia Económica y Social, Tandil.

Long, N. 1992 Battlefields of Knowledge (Londres: Routledge).

Manzanal, M. 1990 "El campesinado en la Argentina: un debate tardío o políticas para el sector: una necesidad impostergable” en Realidad Económica (Buenos Aires) $\mathrm{N}^{\circ} 97$.

Manzanal, M. 1993 Estrategias de sobrevivencia de los pobres rurales (Buenos Aires: CEAL).

Martínez de Ibarreta, R.; Pucciarelli, A. y Posada, M. (comps.) 1994 Estudios agroindustriales (Buenos Aires: CEAL).

Murmis, M. 1994 "Algunos temas para la discusión en la Sociología Rural latinoamericana: reestructuración, desestructuración y problemas de excluidos e incluidos" en Ruralia. Revista Argentina de Estudios Agrarios (Buenos Aires: FLACSO) $\mathrm{N}^{\circ}$ 5, septiembre.

Murmis, M. 1996 "Pobreza rural y ocupación: revisión de algunos datos inéditos” en Revista Estudios del Trabajo (Buenos Aires) No 12, agosto-diciembre.

Nun, J. y Lattuada, M. 1991 El gobierno de Alfonsín y las corporaciones agrarias (Buenos Aires: Manantial).

Racedo, J. 1988 Crítica de la vida cotidiana en comunidades campesinas. Doña rosa, una mujer del noroeste argentino (Buenos Aires: Cinco).

Soverna, S. 1995 "Sistematización de estudios de casos de pobreza rural”, informe final (Buenos Aires: SEAGyP, PROINDER).

Taylor, C. 1948 Rural life in Argentina (Louisiana: Louisiana University Press).

Tenembaum, J. L. 1948 Orientación económica de la agricultura argentina (Buenos Aires: Losada).

Teubal, M. 1995 "Notas sobre la mano de obra excedentaria del tercer mundo" en Teubal, M. et al Globalización y expansiónagroindustrial. ¿Superación de la pobreza en América Latina? (Buenos Aires: Corregidor).

Tsakoumagkos, P. 1992 Manual de evaluación económica para proyectos de mejoramiento ambiental del hábitat popular urbano (Buenos Aires: GTZ-SVCA, 
Agencia Alemana de Cooperación Técnica, Secretaría de Vivienda y Calidad Ambiental).

Tsakoumagkos, P. et al. 1988 "Algunos límites ideológicos, conceptuales y económicos del discurso ecológico ambiental” en Yanes, L. (ed.) Aportes para el estudio del espacio socioeconómico II (Buenos Aires: El Coloquio). 